\title{
IDENTITETSDANNELSE I DE FØRSTE KRISTNE MENIGHEDER
}

\author{
Birgitte Graakjær Hjort
}

\section{Indledning}

Identitetsdannelse er et emne, som har optaget mennesker til enhver tid. Jeg vil indledningsvis citere Menander fra det tredje århundrede f.Kr.: "In many ways the saying 'know yourself' is not well said. It were more practical to say 'know other people"” (jf. Brown 2000, 78f). Udsagnet rummer en betydelig indsigt i identitetsdannelse. Når jeg gør det til mit udgangspunkt, skyldes det, at det angiver et afhængighedsforhold mellem menneskets opfattelse af sig selv og af andre mennesker. Afhængighedsforholdet viser sig bl.a. ved, at mennesket sammenligner sig med andre, når det former sin identitet. Netop sammenligningens rolle i den proces, som identitetsdannelse er et udtryk for, vil jeg sætte fokus på.

Metodisk anvender jeg identitetsteorier, som i overvejende grad er udviklet på grundlag af socialantropologiske og gruppepsykologiske undersøgelser. Det er dermed teorier, som søger at afdække nogle udbredte, almenmenneskelige mekanismer snarere end nogle specifikt religiøse. Min påstand er, at mennesker ofte tænker og handler ud fra sammenligning uden nødvendigvis at være sig det bevidst. Hvis en f.eks. siger: “Akademikere er for dårligt lønnede nu om dage”, forudsætter vedkommendes udsagn en forestilling om og et kendskab til, at andre faggrupper er bedre lønnede. For hvordan skulle nogen kunne udvikle et begreb om lav løn, hvis ikke der var nogen, som var højt lønnede? Eller hvis nogen siger: "Mozart var musikalsk", ville udsagnet ikke være adækvat, hvis alle mennesker var lige så musikalske som Mozart (jf. Brown 2000, 31522 og 1984, 603-23, vedrørende forskellige former for lighed).

Eksemplerne tjener til at godtgøre min påstand om sammenligningens grundlæggende betydning for selvopfattelse og identitetsdannelse. Det er imidlertid ikke akademikeres lønniveau eller Mozarts musikalitet, der skal gøres til genstand for en nærmere analyse, men sammenligningens rolle hos Paulus, når han forsøger at omdefinere en jødekristen opfattelse af, hvem der er Abrahams børn og dermed de sandt troende. ${ }^{1}$ Jeg vil beskæftige mig med et diskursivt møde, hvor Paulus bliver eksponent for en transformation og reinterpretation af en eksisterende religiøs tradition. Det drejer sig således i høj grad om religiøs identitet i forandring, jf. temanummerets undertitel, idet Paulus går i kritisk dialog med en hævdvunden tolkning af, hvem der har ret til at opfatte sig som Abrahams børn, når han argumenterer for, at det er de Kristus-troende og ikke de omskårne, som overholder Moseloven.

\footnotetext{
${ }^{1}$ Det eksegetiske arbejde, der ligger til grund for tekstmaterialet, som inddrages i nærværende artikel, er behandlet mere udførligt i Hjort 2002, 43-67.
} 
Valget af teoretisk udgangspunkt inden for socialantropologi og gruppepsykologi giver mulighed for at afdække de almenmenneskelige aspekter af religiøs identitet samt anledning til dialog på grundlag af arbejder med vidt forskelligt empirisk materiale. En af begrænsningerne består til gengæld i, at der ikke i udgangspunktet tages højde for det specifikt religiøse, i mit tilfælde det paulinske, ej heller for det, der adskiller forskellige typer af social identitet. Jeg sigter til, at der kan være forskel på, hvordan mennesker identificerer sig med sociale grupper: Når nogen identificerer sig med f.eks. en familie, en faggruppe, en religiøs gruppe eller en nation, er det ikke nødvendigvis de samme mekanismer, der finder sted i alle tilfældene, ligeså vel som graden af tilknytning til de forskellige grupperinger kan variere (Brown 2000, 338f).

I erkendelse af, at enhver metodisk tilgang har sine muligheder og begrænsninger, vil jeg med den valgte tilgang til stoffet koncentrere mig om, hvordan Paulus har forsøgt at fastholde en gruppe af tidlige kristne menigheder på en fælles religiøs identitet ved at bibringe dem en ny fortolkning af allerede hævdvundne religiøse traditioner inden for jødekristne kredse. En definition af de mest centrale begreber er imidlertid nødvendig.

\section{Begreberne identitet, identificere, identifikation og social identitet}

Begrebet identitet, på latin identitas, indeholder roden idem, som anvendes i betydningen “(det/den) samme”. Når A siges at være identisk med B, angives det således, at der er noget, som er det samme ved A og B - noget, der er lig med hinanden. Når jeg taler om, at et menneske identificerer sig med andre eller andet, bruger jeg begrebet som betegnelse for en psykologisk proces, hvor et individ eller en gruppe overtager egenskaber, karakteristika og historie fra et ydre objekt, f.eks. en anden person. Identitet er dermed summen af identificeringer foruden en række kendetegn ved personen eller gruppen selv, det være sig holdninger, anlæg m.m.

Richard Jenkins gør i bogen Social Identity (1996) rede for, hvordan begrebet identitet indeholder både konceptet absolut lighed (A er identisk med B) og samtidig konceptet forskellighed: Noget er fælles for A og B (lighed), mens andet adskiller A og $\mathrm{B}$, således at det er muligt at skelne dem fra hinanden som distinkte størrelser. Enhver tale om identitet forudsætter således både lighed og forskel. Udtrykt med Jenkins’ egne ord: "Taken - as they can only be - together, similarity and difference are the dynamic principles of identity, the heart of social life” (s. 4). Med verbet identificere betegnes noget aktivt, som underbygger hypotesen om, at identitet ikke primært er en statisk størrelse, men noget, som kontinuerligt dannes. Identitet er ikke noget, som blot foreligger, men snarere noget, som bliver til.

Enhver tale om identitet og identifikation bygger på den forudsætning, at personer, grupper og fænomener m.m. kan klassificeres, således at en person kan forbinde sig selv med noget eller nogen bestemt, f.eks. et familiemedlem, en helt eller en filosofisk retning. Jeg deler en af Jenkins’ grundlæggende præmisser, som består i, at menneskelig identitet og identifikation er sociale i den forstand, at de forudsætter interaktion (sml. Naylor 1996, 1-13 og 37-60 om interaktion som det mest centrale omdrejningspunkt for formning af gruppers identitet). Der skal være nogen eller noget at ligne og at adskille 
sig fra. Social identitet vedrører vor forståelse af, hvem vi er, og hvem andre er - og det vedrører for den sags skyld det reciprokke forhold, dvs. andre menneskers forståelse af sig selv såvel som af andre.

Når vi kommunikerer med og informerer hinanden, opererer vi i udpræget grad med kollektive størrelser. Vi taler f.eks. om mænd eller kvinder, børn eller voksne, læger eller sygeplejersker, muslimer eller kristne osv. Derved forudsætter vi social identitet af kønslig, faglig, religiøs eller anden art. Sprogbrugen i sig selv afspejler en beskæftigelse med, hvem vi er, og hvem andre er. Det gælder på tværs af kultur, religion og sprog. Hvis ikke vi kommunikerede på den måde om og til hinanden, ville Jeg og Du være det samme (Jenkins 1996, 3-6 og 80f; endvidere Hogg og Abrams 1992, 1-2 og 102, om mennesket som socialt selv).

Både de klassifikatoriske forudsætninger og de psykologiske mekanismer, som jeg her har gjort rede for i forbindelse med de fire begreber identitet, identificere, identifikation og social identitet, vil jeg i det følgende eksemplificere og uddybe med tekstmateriale, som er hentet fra Det nye Testamente, mere præcist fra et af Paulus’ hovedbreve, Galaterbrevet.

\section{Dannelse af social identitet belyst med Tajfel og Turners teorier}

De termer, som anvendes i Galaterbrevet til beskrivelse af de kristne som menighedsmedlemmer, er i påfaldende grad kollektive, idet de indkredser dem som gruppe ved at tilskrive dem en række fælles kendetegn og titler såsom: hinandens brødre (Gal 1,11; 3,15; 4,12.28.31; 5,11.13 og 6,1.18), Abrahams sønner (Gal 3,7, jf. også 3,29), Guds sønner (Gal 3,26 og 4,(5-)6), Paulus’ børn (Gal 4,19) og de åndelige (Gal 6,1) (Esler 1996, 226f). ${ }^{2}$ Også de jødekristne missionærer omtales i pluralis som en gruppe (jf. Gal 1,7 og 5,12, undtagelse i Gal 5,10). Paulus fokuserer på familiemetaforer, hvilket underbygges af brevets indledende tale om Gud som fader (Gal 1,1.3.4). Det vil jeg vende tilbage til. Der er stort set ingen interesse for enkeltpersoner, med mindre disse præsenteres og diskuteres som repræsentanter og prototyper. Det er f.eks. tilfældet med Abraham, der hos Paulus fremstilles som repræsentant for de troende, åndsudrustede og frie, og Peter, der som enkeltperson bliver et eksempel på de jødekristne, der undgår måltidsfællesskab med uomskårne (Gal 2,11-21).

De sociale kategoriseringer udstyrer gruppen med et sæt af værdier, roller og kendetegn, som de forventes at identificere sig med. Når Paulus på denne måde søger at skabe og definere en kristen identitet ved at give gruppens medlemmer en række sociale identifikationsmarkører, gør han brug af termer, som i vid udstrækning angiver noget relationelt og komparativt, så medlemmerne kan afgrænse sig i forhold til andre (Barth

\footnotetext{
2 Henvisningerne er eksempler på kollektive identifikationsmarkører i Galaterbrevet og den kognitive proces, som erkendelse af tilhørsforhold til en gruppe kan betegnes som.
} 
1998, 10-12 og 14-16 om gruppers indbyrdes afgrænsninger). Det relationelle ser vi eksemplificeret ved identifikationen af menighedmedlemmerne som hinandens brødre. Med denne betegnelse skildres de som en gruppe, der indgår i nære familierelationer. Det komparative fremgår af identifikationen af dem som frie, troende og åndsudrustede. Disse udgør en attraktiv gruppe i forhold til slaver, lovbundne og kødelige. Samtidig indebærer de anvendte identifikationsmarkører en afgrænsning af gruppen i forhold til andre: De, der ikke er brødre, frie, troende, åndsudrustede etc., tilhører ikke gruppen.

Henri Tajfel og John Turner, som har medvirket til at grundlægge den moderne gruppepsykologi, har bl.a. været optaget af at placere individer i deres sociale og kulturelle kontekst samt undersøge de sociale systemer, som mennesker lever i. I deres analyser af social identitet gør de rede for, hvorledes individets selvopfattelse afledes af sociale kategorier, som vedkommende opfatter sig selv inden for. Med termen social identitet henviser de til aspekter af et individs selvbillede, som er afledt af netop disse kategorier. Dannelsen af social identitet sker således på grundlag af kategorier, der markerer tilhørsforhold. Der er tale om en dannelsesproces, som ifølge Tajfel og Turner forudsætter og er kendetegnet ved tre grundlæggende forhold: For det første søger individer at opnå, bevare eller forøge en positiv social identitet (sml. Brown 2000, 311f, 329 og 334). For det andet bliver sociale kategorier og medlemskab af sociale grupper forbundet med positive eller negative værdikonnotationer. En positiv social identitet er afhængig af, at ingroup ikke blot kan opfattes positivt, men positivt forskellig fra relevante outgroups. Derved bliver det muligt at foretage nogle favorable sammenligninger mellem ingroup og relevante outgroups. Hvis, for det tredje, social identitet er utilfredsstillende, vil gruppens medlemmer enten søge andre grupper, som de bedømmer mere positivt, og/eller øge fokus på deres egen gruppes positive særpræg. Bedømmelse af egen gruppe afhænger af sammenligninger med andre relevante grupper. Konstatering af en positiv forskel mellem ingroup og outgroups fører til høj prestige, mens en negativ forskel i sammenligning mellem ingroup og outgroups fører til lav prestige blandt ingroups medlemmer (Tajfel og Turner 1986, 40; Turner 1984, 528-529; endvidere Oakes og Turner 1994, 82-86; Turner 1982, 18 og 34-36). ${ }^{3}$

Tajfel og Turners teorier om social identitet bidrager til at kaste lys over de konkrete stridigheder om kristen identitet i Galaterbrevet. Det sker ved, at deres analyser forudsætter en nær sammenhæng mellem dannelse af social identitet (alias gruppeidentitet) og sammenligning med relevante outgroups. Netop denne sammenhæng er dominerende i Galaterbrevet. Dernæst bidrager ovennævnte tre punkter til at præcisere den rolle, de såkaldte ‘modstandere’ spiller i Galaterbrevet i Paulus’ strategier

\footnotetext{
${ }^{3}$ Foruden en uddybning af ovenstående belyser Turner her, hvorledes social identitet indebærer at blive inkluderet i nogle kategorier og udelukket fra andre. Begge dele bidrager til at bestemme, hvad en person er, og hvad han/hun ikke er.
} 
og deraf følgende argumentation for det attraktive i en kristen identitet. Før jeg uddyber disse to forhold, vil jeg præsentere Tajfel og Turners identitetsteorier nærmere.

Deres grundlæggende hypotese, som tager udgangspunkt i "intergroup differentiation", består i, at "pressures to evaluate one’s own group positively through ingroup/outgroup comparisons lead social groups to attempt to differentiate themselves from each other” (Tajfel og Turner 1986, 40f). I hvert fald tre variabler øver indflydelse på en sådan "intergroup differentiation”: For det første skal individer have internaliseret gruppemedlemskabet som en del af deres selvopfattelse, dvs. de skal subjektivt identificere sig med den relevante ingroup. Det er ikke tilstrækkeligt, at andre definerer dem som en gruppe. Dernæst skal situationen tillade og give mulighed for, at der mellem grupper bliver foretaget sammenligninger, som muliggør selektion og vurdering af relevante egenskaber og kendetegn. Ikke alle forskelle mellem grupper er værdiladede, og de forskelle, der tilskrives positiv eller negativ værdi, kan variere fra gruppe til gruppe. For det tredje sammenligner en ingroup ikke sig selv med hvilke som helst outgroups, men med dem, der opfattes som relevante (jf. Brown 2000, 78-81 om valget af sammenlignelige andre og ikke tilfældige andre, som personer eller grupper bedømmer sig selv i forhold til). På grundlag af disse tre variabler konstaterer Tajfel og Turner, at "The aim of differentiation is to maintain or achieve superiority over an outgroup on some dimensions. Any such act, therefore, is essentially competitive. This competition requires a situation of mutual comparison and differentiation on a shared value dimension" (1986, 41).

Som nævnt tjener Tajfel og Turners teoretiske overvejelser til at kaste lys over og præcisere indholdet af identitetskrisen og de diskussioner, den har affødt, i Galaterbrevet. En af Paulus' overordnede hensigter med affattelsen af brevet har været at overbevise de galatiske kristne om hans tolkning af Abrahamskikkelsen. Paulus har lanceret en forståelse, som indebærer en ny definition af, hvem Abrahams børn var. Herigennem har han søgt at motivere galaterne til at identificere sig selv med Abrahams børn og hinandens brødre for derigennem at internalisere gruppemedlemskabet. At identitetsspørgsmålet dermed bliver centreret om familierelationer er ikke tilfældigt, eftersom familien/slægten var den relation, der var af mest vital betydning for gruppeidentitet i de antikke mediterrane kulturer. Netop de familiære relationer var de basale mellemmenneskelige relationer, hvorudfra en person fik tilskrevet værdi (ære) og vedkommendes tilhørsforhold til andre blev bestemt. Med Tajfel og Turners terminologi er der tale om dannelse af social identitet. En af de grundkategorier, som menighedens fælles identitet afledes af, er således Abrahamfamilien. Det er gennem tilhørsforholdet til Abraham, at menighedsmedlemmerne opnår eller forøger deres positive sociale identitet.

Det, som på en særlig måde bliver belyst af Tajfel og Turner i deres teoretiske overvejelser over denne dannelsesproces og dens tilskrivning af positive værdier til den gruppe, hvis identitet søges formet, er sammenligning med andre grupper. Her bidrager teorierne til at klargøre og uddybe de strategier, Paulus anvender, når han søger at overbevise sine tilhørere om sociale grundkategorier og ærefulde personer, som de kristne tilskyndes til at identificere sig med. Hvad Paulus' argumentationsform angår, er 
det påfaldende, i hvilket omfang han opererer med diametrale modkategorier såsom frie kontra slaver, troende kontra lovbundne, åndsudrustede kontra kødelige. Hvad indholdet af den kristne identitet angår, er der en bemærkelsesværdig koncentration om begreber som frihed (Gal 4,21-31; 5,1.13), ånd (Gal 3,2-5; 4,29; 5,18.25) og tro (Gal 3,2.5.79.11-12.14.22.23-26). Når disse gøres til de overordnede kristne egenskaber og kendetegn, sker det vel at mærke ved, at de fremstilles som kontraster til deres modsætninger, henholdsvis trældom, kød og lovbundethed (træl kontrasteres til fri, Gal 3,28; 4,22-23.25-26.30-31 og 5,1; ånd til kød, Gal 3,3; 4,29; 5,16-17 og 6,8; tro til lov, Gal 3,2.4.11-12.23). ${ }^{4}$

I den nytestamentlige eksegese er denne kontrasttænkning ofte blevet forklaret historisk som udtryk for, at Paulus svarer tilbage på jødekristne missionærers synspunkter (Betz 1994, 55f; Dunn 1993, 9-11; Howard 1979, 1-19 og 83-86). Brevet er således bestemt af en polemisk kontekst, som har ført Paulus til at forholde sit budskab til et mod-budskab. Derfor har det ikke været tilstrækkeligt positivt at argumentere for en bestemt opfattelse af kristen identitet uden samtidig at placere opfattelsen i forhold til modstandernes. Resultatet er blevet en redegørelse for, at de kristnes identitet er båret af frihed, åndsudrustning og tro til forskel fra modstanderne, hvis identitet er indbegrebet af kontrasterne, nemlig slaveri, kødelighed og ufrihed. Komplementært med denne forklaring, som bygger på et forsøg på rekonstruktion af brevets oprindelige foranledning, kan man hævde, at Paulus i sin kontrasttænkning gør brug af virkemidlet stereotypisering, hvorved han forenklende betoner såvel den fælles, attraktive identitet for ingroup som den fælles, ufavorable identitet for outgroup (Hogg og Abrams 1992, 73-75 og 107; Tajfel 1981, 144-167; jf. også Dovidio m.fl. 1996, 276-319, om hvad stereotypisering og diskrimination viser om de dynamiske relationer mellem grupper).

Tajfel og Turners identitetsteorier udelukker ikke disse forklaringsmodeller, men specificerer funktionen af kontrasttænkningen i den proces, som identitetsdannelse er et udtryk for i Galaterbrevet. Den tilbagevendende adversative opstilling og uddybning af identitetsmarkører i brevet lader sig nemlig ikke forklare fyldestgørende, hverken med henvisning til den historiske situation eller med henvisning til stereotypisering som virkemiddel. Til disse forklaringsforsøg føjes yderligere en dimension, som består i, at social identitetsdannelse fremmes af, at en positiv indholdsbestemmelse af en given identitet suppleres af en negativ beskrivelse af dens postulerede modsætning. Det har med andre ord ikke været tilstrækkeligt at agitere for, hvorledes de kristne kunne

\footnotetext{
${ }^{4}$ Flere af kontrasterne fortolker gensidigt hinanden, således at kød også sættes i modsætning til frihed, Gal 5,13, og ånd med lov, Gal 5,18. Foruden de nævnte, tilbagevendende kontrastpar opererer Paulus med flere enkeltstående kontraster som lov versus løfte, Gal 3,18; kød versus løfte, Gal 4,23, og trællekår versus sønnekår, Gal 4,7.
} 
identificere sig med de frie, hvis ikke der var et modstykke ladet med negative værdikonnotationer, nemlig slaverne. Det positive særpræg ved identifikationen med de frie fremtræder først med overbevisning og klarhed, når det sættes i kontrast til sin modpol. Derved bliver det sammenligningen med de relevante outgroups, der muliggør en selektion og internalisering af de anførte, positive egenskaber og kendetegn. At det netop er internalisering af gruppemedlemskabet og dannelsen af en fælles identitet, således at den enkelte opfatter sig som en del af menigheden som ingroup, Paulus sigter mod, snarere end andres definition af dem som gruppe, er evident ud fra Galaterbrevets adressater: menighederne i Galatien (Gal 1,2b).

Fordi sammenligning med relevante outgroups spiller så konstitutiv en rolle i dannelsen af social identitet, centreres Paulus' argumentation vedrørende kristen identitet om det, der adskiller de kristne fra alle andre, frem for det, de er fælles med andre om. Det indebærer imidlertid ikke, at han argumenterer ud fra et helt nyt værdigrundlag. Tværtimod ligger det implicit i sammenligningen og kontrasteringen med relevante outgroups, at grupperne i vidt omfang deler opfattelse af, hvilke identitetsmarkører, der er positive, og hvilke, der er negative. In- og outgroups har således i vid udstrækning samme værdisystem.

Den mest relevante outgroup i Galaterbrevet er en gruppe jødekristne missionærer, ${ }^{5}$ der deler Paulus’ værdigrundlag, når det gælder attraktionen i at identificere sig med Abrahams børn gennem hans frie kvinde Sara frem for Abrahams børn gennem hans trælkvinde Hagar. Til gengæld adskiller Paulus sig markant fra disse jødekristne missionærer, når det gælder legitimeringen af de fælles værdier og identitetsmarkører (Tajfel og Turner 1986, 43). Han identificerer de uomskårne troende, der ikke er bundet af loven, frem for de omskårne lovlydige med Saras børn, de frie og åndsudrustede (Gal 4,21-31). Dermed omkalfatrer han grundlaget for identifikationen på en måde, som ikke blot har relativeret den relevante outgroup's position, men ligefrem diskrimineret den. ${ }^{6}$ Ved hjælp af denne 'social competition'-strategi søger han at tilskrive de (hedninge)kristne en positiv værdiladet, distinktiv identitet. Han artikulerer dermed den kristne identitets særpræg ved at dikotomisere og polarisere de paulinske kristne og de jødekristne i en sådan grad, at hans konkurrence- og grænsedragningsstrategi uvægerligt må have indbudt til konflikt, omend vi ikke har nogen bevidnelse af, hvordan de jødekristne missionærer har reageret på Galaterbrevet.

\footnotetext{
${ }^{5}$ Modsat antagelsen af en dobbelt front, dvs. både en jødekristen og en gnostisk inspireret, penumatisk og libertinisk outgroup. Denne tofrontshypotese har været repræsenteret af især Lütgert 1919 og Ropes 1929. Hypotesen er blevet diskuteret indgående i løbet af det tyvende århundrede af blandt andre Schmithals 1984, 37-40; Schmithals 1965, 9-46. Schmithals gør op med tofronthypotesen og argumenterer for, at den givne outgroup i Galaterbrevet er gnostisk inspirerede jødekristne. Der er fremført overbevisende belæg imod antagelsen af en dobbelt front af blandt andre Duke 1990, 94 og Dunn 1993, $285 f$.

${ }^{6}$ Ikke mindst Boyarin 1994 har vist, hvorledes Paulus’ teologi har virket provokerende og diskriminerende på jøder i samtiden. Se endvidere Betz 1988, 423, vedrørende Paulus’ angreb på jødekristne i Gal 4,25, hvor han henviser til jødisk selvforståelse med det ene formål at karikere den og fremstille jødekristen livsstil som en trælletilværelse.
} 


\section{Dannelse af social identitet gennem adskillelse}

Inden for forskningen i social identitet er der foretaget en række undersøgelser af gruppers forsøg på at opnå og bevare en positiv anderledeshed i forhold til andre grupper. F.eks. antager Brown, at sammenligning af grupper er en del af forudsætningen for at opnå social identitet og integritet i en gruppe. Det skal forstås på den måde, at gruppers søgen efter anderledeshed har den funktion, at gruppen og det enkelte individ derigennem opnår en positiv bedømmelse af sig selv ved hjælp af associationer til en favorabelt betragtet ingroup (Brown 2000, 311 og 326; 1984, 21-33). Det er denne side af identitetsforskningen, der skal uddybes i det følgende.

Tajfel og Turners tale om, at positiv bedømmelse af egen gruppe sker gennem sammenligning med og adskillelse fra andre grupper - som jeg tidligere var inde på underbygges af Jenkins’ undersøgelser af social identitet. Dog betones adskillelsesaspektet mindre hos Jenkins, der afdækker fænomenet identitetsdannelse som en proces, der udfolder sig, hvor mennesker forholder sig til både ligheder og forskelle mellem sig selv og andre (jf. tidligere anført citat af Jenkins). Mennesker skal således have noget tilfælles og dele kriterier for identifikation for at kunne udgøre en gruppe (Jenkins 1996, 104).

I praksis bliver det dog på en vis måde, i analogi med Tajfel og Turner, forskellen, der kommer i centrum hos Jenkins. Talen om social identitet giver nemlig kun mening, når der er nogle, som individer eller grupper adskiller sig fra (s. 4). Dette svarer til, at lighed ikke kan erkendes uden forskellighed: At blive indbefattet i en gruppe er ikke muligt uden en grænsedragning i forhold til det/dem, man dermed ikke tilhører. Lighed og forskellighed genspejler hinanden på tværs af en grænse, således at individ eller gruppe først opdager, hvad de er, dvs. hvori deres lighed består, når de står ved en grænse, som sætter dem i stand til at registrere, hvad de andre er, dvs. erkende, hvori forskelligheden består. Uden denne opdagelse af lighed gennem forskellighed ville definitionen af et 'vi' i forhold til et 'dem' slet ikke være mulig. 'Vi' opdager med andre ord først, hvad vi er, når vi står ved en grænse, der viser, hvad vi ikke er. Det, som binder individer sammen til en gruppe (lighed), et kollektiv, er således kendetegn, som adskiller dem fra andre (forskel). Ellers ville ‘vi’ være ligesom ‘dem’ (s. 6 og s. 80f).

I Galaterbrevets diskurser om identitet finder vi et komplekst samspil mellem på den ene side Paulus’ videreførelse af jødiske identitetsmarkører, hvorved ligheder mellem jødisk og kristen identitet betones, og på den anden side så gennemgribende en omdefinering og reinterpretation af jødekristne traditioner, at de jødekristne kun kan have opfattet det som et opgør fra Paulus’ side. Paulus kunne principielt have valgt at foretage sit opgør med de jødekristne missionærer ved udelukkende at argumentere for de kristnes identitet som frie. Dette kunne være sket i form af en forkyndelse af Kristus som befrier (Gal 5,1) og af de Kristustroende som de befriede (Gal 5,1.13, Hjort 2000, 92-99). Det er imidlertid evident, at talen om frihed i Galaterbrevet underbygges og profileres af de advarende toner imod frihedens modsætning, nemlig slaveri. Paulus appellerer med andre ord til, at de kristne skal se det særegne i deres fælles identitet (lighed) ved bl.a. at opdage modstykket hertil. For hvori består det attraktive i at tilhøre 
en gruppe af frie, hvis ikke risikoen er til stede for at blive slaver? Såvidt gør Paulus brug af den mekanisme, Jenkins har beskrevet som genkendelse af lighed og fællestræk i en gruppe på baggrund af forskel og adskillelse fra andre.

Identitetsdiskurserne i Galaterbrevet er som sagt komplekse. Samtidig med, at Paulus søger at overbevise sine tilhørere om et bestemt budskab om identitet ved at betone gruppens særkende i kontrast til især de jødekristne som outgroup, bygger hans argumentation på jødisk traditionsstof i en sådan grad, at han ikke konstruerer noget nyt forstået som et absolut novum. Han erkender således ikke kun ligheder på baggrund af forskelle, men reinterpreterer snarere eksisterende jødiske værdisæt. Dannelsen af et fælleskristent 'vi' sker dermed ikke alene ved hjælp af en grænsedragning i forhold til et jødekristent 'dem', men samtidig ved hjælp af en anerkendelse af jødiske værdier og et indirekte postulat om at være rette arvtagere af traditioner, de jødekristne som outgroup også har gjort krav på. I den proces, som identitetsdannelsen i Galaterbrevet afspejler, har ligheder mellem Paulus’ og den jødekristne gruppes teologi ikke blot foranlediget brevet, men desuden i videre forstand sat dagsordenen for, hvilke identitetsmarkører, der gøres til de centrale. Årsagen skal søges i det forhold, at de jødekristne og de (paulinske) kristne ${ }^{7}$ har lignet hinanden tilstrækkeligt til, at de galatiske kristne - både jøde- og hedningekristne - har betragtet de jødekristne missionærers synspunkter som en videreførelse af Paulus’ oprindelige forkyndelse for galaterne. Paulus derimod har regnet de jødekristnes forkyndelse, herunder deres krav om omskærelse, for indbegrebet af et helt andet evangelium, som ifølge Paulus ikke kan anerkendes som et evangelium (Gal 1,7(-9)).

Lighederne mellem Paulus’ forkyndelse og øvrig jødisk tro underbygges ikke blot af en række fællestræk, hvad angår idéer og praksis, men samtidig af organisationsform. I begyndelsen af sit virke underviste Paulus i synagogerne, hvilket taler for, at han har opfattet sig som reformator inden for jødedommen og i vid udstrækning også er blevet opfattet som sådan (Bilde 1999, 148-176, særligt 163f). ${ }^{8}$ Men de jødiske krav om omskærelse og overholdelse af visse renheds- og madforskrifter har vanskeliggjort en fuld assimilation af proselytter og gudfrygtige i de jødiske fællesskaber, som dermed trods indoptagelse af konverterede hedninger vedblev at have et vist etnisk præg (Taylor 1995, 132). Adgangen til de paulinske fællesskaber har været betragteligt lettere. Til gengæld har den fordret en grænsedragning mellem kristne og andre jødiske grupper. Denne i første omgang mere uforpligtende adgang til de kristne grupper har fået Paulus til at trække en skarp grænse, ikke mellem omskærelse eller ej, heller ikke mellem mad-

\footnotetext{
${ }^{7}$ Sondringen er problematisk, eftersom de jødekristne i Galatien ikke har set de Kristustroende som en anden gruppe end den, de selv har tilhørt, men tværtimod har opfattet sig selv som Kristustroende, der varetog den jødiske arv. Når jeg alligevel indfører distinktionen, sker det med henblik på at skelne mellem de jødekristne missionærer, hvis adgangskrav til menigheden Paulus opponerer imod (outgroup), og de paulinske Kristustroende, dvs. dem, der har ladet sig overbevise af Paulus, heriblandt de hedningekristne, som ikke har ladet sig omskære (ingroup).

${ }^{8}$ Dog taler de tilbagevendende stridigheder mellem Paulus og jøderne i synagogerne for, at der samtidig har været afgørende uoverensstemmelser mellem dem (jf. især ApG, f.eks. ApG 13,13-52; 17,1-9 og 18,5f).
} 
/renhedsforskrifter eller ej, men mellem tro og lovoverholdelse, frihed og ufrihed samt mellem åndsudrustning og såkaldt kødelighed. Ikke mindst hans applicering af denne grænse på de moralske forhold har trukket et skarpt skel mellem dem, der lever efter ånden, og dem, der lever efter kødet (jf. Gal 5,13-6,10, især 5,16-24). Her gives der ikke plads til nogen form for mellemeksistens med dertil hørende moralsk adiaforon. Det er således nærliggende at antage, at det netop er lighederne sammen med de jødekristnes krav om praktisering af omskærelse og overholdelse af mad- og renhedsforskrifter for at opnå fuld initiation, der har ført Paulus til de skarpe grænsedragninger.

For de jødekristne missionærer såvel som for de Paulustilhængere, der har været ved at lade sig overbevise af dem, har lighederne mellem grupperne været så slående, at de næppe har haft bevidstheden om en egentlig grænse mellem to grupper. Her over for har Paulus trukket grænsen skarpt op ved at understrege forskellene mellem de jødekristne og de paulinske kristne, som han brevet igennem forsøger at bibringe en fælles identitet, der profileres ved dens forskellighed fra de jødekristnes. Forskellene specificeres til modsætningen mellem at have Sara og Hagar til stammoder, mellem at leve som frie og som slaver samt mellem at være henholdsvis åndsudrustede eller kødelige. Tilhørsforholdet til menighederne konstrueres således som et svar på de jødekristnes omskærelseskrav. Den fælles identitet skabes i spejling med andre, i dialektikken mellem ligheder og forskelle, konkret i form af en ny tolkning af den jødiske arv (Abrahamfortællingerne) og med betoning af de kristnes anderledeshed i forhold til de omskårne jødekristne, som krævede lovoverholdelse. Det er de slående ligheder, der har forstærket behovet for at betone forskellighederne. Paulus' tilbagevendende sammenligning i form af kontrastopstillinger af identitetsmarkører samt appellen til galaternes erkendelse af forskellighed fører i Galaterbrevets tilfælde til en negativ bedømmelse af 'de andre' (diskrimination).

Inden for social identitetsteori har der været foretaget grundige analyser af de processer, der finder sted, når den positive bedømmelse af individet og/eller dets gruppe sker gennem favorisering af ingroup på bekostning af kvaliteterne ved outgroups (f.eks. Tajfel og Turners arbejder). Det er denne side af social identitetsdannelse, jeg har koncentreret mig om. Det bør dog nævnes, at der i andre sammenhænge end den galatiske kan skabes en positiv social identitet for en gruppe, uden at identifikationens styrke og signifikans afhænger af en negativ bedømmelse af andre grupper, men hvor den sker i et harmonisk samarbejde og samspil mellem grupper (Brown 2000, 333-41). Lad mig gribe tilbage til eksemplet i indledningen om højt- og lavtlønnede: Viden om, at andre er lavtlønnede, gør det ikke mere attraktivt at være højtlønnet, heller ikke selvom forskellen mellem løntrinnene øger bevidstheden om at være højt- eller lavtlønnet.

\section{Konklusion}

Ved at belyse dialektikken i Galaterbrevet mellem lighed og forskel ved hjælp af socialantropologiske og gruppepsykologiske identitetsteorier, viser der sig at være grundlæggende fællestræk, som flere grupper ønsker at identificere sig med. Det gælder 
f.eks. fælles religiøse traditioner og værdier. Netop det, som deles af flere og er fælles for A og B, udgør i Galaterbrevet omdrejningspunktet for det, der adskiller A og B, så de ikke blot kan skelnes fra hinanden, men konkurrerer med og diskriminerer hinanden. Det er således ikke blot en persons gruppetilhørsforhold, der bidrager til den pågældendes forståelse af sig selv. Bevidstheden om de andre grupper, som personen ikke tilhører, men distancerer sig fra, spiller på tilsvarende måde en konstitutiv rolle for identitetsdannelse.

Det anvendte tekstmateriale har for det første vist, hvorledes en gruppes identitet formes ved hjælp af sammenligning af sig selv med andre, for det andet hvorledes sammenligningen fører til favorisering af egen gruppe og afgrænsning i forhold til andre. Hvad det første angår, har vi set et eksempel på, hvorledes det attraktive ved de ligheder, som udgør en gruppes fælles identitet, fremhæves ved betoning af, hvori de positivt adskiller sig fra andre gruppers kendetegn. Det kan forklares kognitivt ved, at opdagelsen af lighed sker i erkendelse af forskellighed mellem in- og outgroup. Erkendelsen af det, som er fælles (lighed), er ganske vist en afgørende generator for en gruppes identitetsdannelse. Denne særlige form for lighed er lighed forstået som positiv anderledeshed. Hvad det andet angår, har vi set, hvorledes afgrænsningen ikke med nødvendighed følger af isolation, men tværtimod opstår i interaktion og som adaption i form af nytolkning af andre gruppers traditioner. De sociale grænser, ${ }^{9}$ som drages, og dikotomiseringen mellem 'medlemmer' (ingroup) og udenforstående (outgroup) kan dermed ændre sig fortløbende i gruppers omgang med hinanden, selvom de ikke desto mindre vedbliver at være en del af gruppens fortsatte selvdefinition. Det er således inadækvat at analysere afgrænsning som et statisk fænomen, der finder sted i dialektikken mellem foreliggende ligheder og forskelle. Fænomenet er snarere dynamisk og finder som sådan vedvarende sted i interaktionen mellem grupper. Kort sagt: afgrænsningen, som sammenligningen fører til, har flydende grænser.

Jeg har valgt at koncentrere mig om teorier, der belyser identitetsdannelsen i Galaterbrevet. Derved har jeg kun sporadisk berørt spørgsmålet om den historiske situation, brevet afspejler. Brugen af identitetsteorierne på det udvalgte tekstmateriale har imidlertid ikke alene bidraget til en præcisering af de processer, som kommer til udtryk i brevet, når det gælder formningen af tidlig kristen identitet, men har samtidig betydning for rekonstruktionen af brevets historiske anledning. I Galaterbrevsforskningen har der været megen fokus på, hvilken status de jødekristne missionærer har tilkæmpet sig i Paulus' fravær. Her ud fra har man forsøgt at bedømme omfanget af den trussel, Paulus har set i denne gruppes virke. Med nærværende artikel er der imidlertid peget på, at konkurrencen med og polemiseringen mod den galatiske outgroup ikke nødvendigvis afspejler en realistisk konflikt mellem to gruppeinteresser, men ligesåvel kan have sin forklaring i den mekanisme, der er beskrevet som dannelse af positiv social identitet ved hjælp af sammenligning med og afgrænsning i forhold til outgroups. Principielt havde der således ikke nødvendigvis været outgroups, som havde

9 Ikke alle grænser er sociale. F.eks. kan der mellem etniske grupper være tale om territoriale grænsedragninger. 
truet homogeniteten af ingroup, men en ingroup, hvis positive særpræg skulle bringes til udtryk.

Paulus har forsøgt at skabe en kristen identitet ved at overbevise galaterne om en række attraktive identitetsmarkører, dels ved at de tilpasser sig den omkringliggende jødiske kultur, som de selv er en del af, dels ved at de afgrænser sig i forhold til denne. Kristen identitet i Galaterbrevets udformning kan således betegnes som en tredje identitet $i$ betydning krystallisation af jødisk tradition og paulinsk reinterpretation. Sammenligning med og afgrænsning i forhold til eksisterende religiøse traditioner har vist sig at være fundamental, når det gælder formning og forandring af de tidlige kristnes identitet.

\section{Litteratur}

BARTH, FREDRIK

1969 Ethnic Groups and Boundaries. The Social Organization of Culture Difference, Illinois.

BETZ, H.D.

1988 Der Galaterbrief. Ein Kommentar zum Brief des Apostels Paulus an die Gemeinden in Galatien, München.

1994 “Geist, Freiheit und Gesetz”, H.D. Betz, ed., Paulinische Studien. Gesammelte Aufsätze III, Tübingen, 46-62.

BILDE, PER

1999 “Ny vin på nye flasker? Grundlæggelsen af kristendommen som en ny religion i hellenistisk-

romersk tid”, Per Bilde og Mikael Rothstein, eds., Nye religioner i hellenistisk-romersk tid og i dag (Religionsvidenskabelige Skrifter 3), Aarhus, 148-176.

BOYARIN, D.

1994 A Radical Jew. Paul and the Politics of Identity, Berkeley.

BROWN, RUPERT

2000 Group Processes. Dynamics within and between Groups, Oxford.

1984 "The effects of intergroup similarity and cooperative vs. competitive orientation on intergroup discrimination”, British Journal of Social Psychology 23, 1984, 21-33.

1984 "The role of similarity in intergroup relations", Henri Tajfel, ed., The social dimension. European developments in social psychology, volume 2, Cambridge, 603-623.

Dovidio, John F., John C. Brigham, Blair T. JOHNSON \& SAMUEL L. GAERTNER

1996 "Stereotyping, Prejudice, and Discrimination: Another Look", C. Neil Macrae, Charles Stangor \& Miles Hewstone, eds., Stereotypes and Stereotyping, New York, 276-319.

DUKE, P.D.

1990 “The Imperative of Freedom: Galatians 5”, Faith and Mission 8, 94-100.

DUNN, H.D.

1993 A Commentary on the Epistle to the Galatians, London.

ESLER, PHILIP F.

1996 "Group Boundaries and Intergroup Conflict in Galatians: A New Reading of Galatians 5:13-6:10”, Mark G. Brett, ed., Ethnicity and the Bible, Leiden, 215-240.

HJORT, BIRGITTE GRAAKJÆR 
2000 The Irreversible Sequence. Paul's Ethics: Their Foundation and Present Relevance, Frankfurt.

2002 “Abrahams børn og hinandens slaver - om identitet og ethos i Galaterbrevet”, Helge Kjær Nielsen, Johannes Nissen og Aage Pilgaard, eds., Skabt til fcellesskab. Festskrift til Sigfred Pedersen, Aarhus, 43-67.

Hogg, Michael A. \& Dominic Abrams

1992 Social Identifications. A Social Psychology of Intergroup Relations and Group Processes, London.

HOWARD, G.

1979 Paul: Crisis in Galatia. A Study in Early Christian Theology, London.

JENKINS, RICHARD

1996 Social Identity, London.

LÜTGERT, W.

1919 Gesetz und Geist. Eine Untersuchung zur Vorgeschichte des Galaterbriefes, Gütersloh.

NAYLOR, LARRY L.

1996 Culture and Change. An Introduction, Westport.

OAKes, Penelope J., S. Haslam, S. Alexander \& John C. Turner

1994 Stereotyping and Social Reality, Oxford.

ROPES, J.H.

1929 The Singular Problem of the Epistle to the Galatians, Cambridge.

SCHMithaLs, WALTER

1984 Neues Testament und Gnosis, Darmstadt.

1965 Paulus und die Gnostiker. Untersuchungen zu den kleinen Paulusbriefen, HamburgBergstedt.

TAJFEL, HENRI

1981 “Social Stereotypes and Social Groups”, John C. Turner \& Howard Giles, eds., Intergroup Behaviour, Oxford, 144-167.

TAJFEL, HENRI \& JOHN TURNER

1986 “An Integrative Theory of Intergroup Conflict”, S. Worchel \& W. Austin, eds., Psychology of Intergroup Relations, Chicago.

TAYLOR, NiCHOLAS H.

1995 "The Social Nature of Conversion in the Early Christian World", Philip F. Esler, ed., Modelling Early Christianity. Social-scientific studies of the New Testament in its context, London, 128-136.

TURNER, JOHN C.

1984 "Social identification and psychological group formation", Henri Tajfel, ed., The social dimension. European developments in social psychology, vol. 2, Cambridge, 518-538.

1982 “Towards a cognitive redefinition of the social group”, Henri Tafjel, ed., Social identity and intergroup relations, Cambridge, 15-40.

\section{Summary}

The forming of social identity is a process by which the common identifications of an ingroup, which provide members with a sense of belongingness, are being compared with and differentiated from relevant outgroups. Theories within social anthropology and group psychology contribute to explain this process and the functions of its complex interplay between similarities and differences. The making of comparisons becomes a competitive act of differentiation, the purpose of which is to achieve or maintain values of the ingroup that 
are held superior to those of the relevant outgroups. The dispute of the letter to the Galatians is an example of the process and its social competition strategy.

\section{Birgitte Graakjær Hjort}

Adjunkt, ph.d.

Institut for Gammel og Ny Testamente

Aarhus Universitet 